\title{
Correction to: Systolic modified Look-Locker inversion recovery myocardial T1 mapping improves the accuracy of T1 and extracellular volume fraction measurements of patients with high heart rate or atrial fibrillation
}

\author{
Hirohiko Shinbo ${ }^{1} \cdot$ Satoshi Tomioka ${ }^{1} \cdot$ Toshihiko Ino $^{1} \cdot$ Keiko Koyama $^{1}$ \\ Published online: 18 November 2020 \\ ๑ Japanese Society of Radiological Technology and Japan Society of Medical Physics 2020
}

\section{Correction to: Radiological Physics and Technology https://doi.org/10.1007/s12194-020-00594-z}

The article "Systolic modified Look-Locker inversion recovery myocardial $\mathrm{T} 1$ mapping improves the accuracy of $\mathrm{T} 1$ and extracellular volume fraction measurements of patients with high heart rate or atrial fibrillation", written by Hirohiko Shinbo, Satoshi Tomioka, Toshihiko Ino, Keiko Koyama, was originally published online on 5 November 2020 with Open Access under a Creative Commons Attribution 4.0 International License, which permits use, sharing, adaptation, distribution and reproduction in any medium or format, as long as you give appropriate credit to the original author(s) and the source, provide a link to the Creative Commons licence, and indicate if changes were made. The images or other third party material in this article are included in the article's Creative Commons licence, unless indicated otherwise in a credit line to the material. If material is not included in the article's Creative Commons licence and your intended use is not permitted by statutory regulation or exceeds the permitted use, you will need to obtain permission directly from the copyright holder. To view a copy of this licence, visit http://creativecommons .org/licenses/by/4.0/.

With the author's/authors' decision to cancel Open Access the copyright of the article changed on 11 November 2020 to $\odot$ Japanese Society of Radiological Technology

The original article can be found online at https://doi.org/10.1007/ s12194-020-00594-z.

Hirohiko Shinbo

h-shinbo@cvc.pref.gunma.jp

1 Gunma Prefectural Cardiovascular Center, 3-12

Kamiizumimachi, Maebashi-shi, Gunma, Japan and Japan Society of Medical Physics 2020 with all rights reserved. The original article has been corrected.

Publisher's Note Springer Nature remains neutral with regard to jurisdictional claims in published maps and institutional affiliations. 